\title{
Pengaruh Desinfektan dan Lama Perendaman pada Sterilisasi Eksplan Daun Sukun (Artocarpus altilis (Parkinson ex. F.A Zorn) Fosberg)
}

\author{
Nur Asni Setiani ${ }^{1{ }^{*}}$, Fitri Nurwinda ${ }^{1)}$, Dewi Astriany ${ }^{1)}$ \\ ${ }^{1)}$ Sekolah Tinggi Farmasi Indonesia, Jl. Soekarno Hatta No. 354, Bandung, Jawa Barat \\ ${ }^{*}$ Alamat korespondensi: nur.asni@stfi.ac.id
}

\begin{abstract}
ABSTRAK
Daun sukun (Artocarpus altilis) merupakan herbal yang banyak dimanfaatkan untuk pengobatan. Kultur jaringan menjadi alternatif dalam meningkatkan produktivitas daun sukun dan metabolit sekunder yang dihasilkannya. Tahap pertama yang menentukan keberhasilan perbanyakan tanaman melalui kultur jaringan adalah teknik sterilisasi. Penelitian ini bertujuan mendapatkan metode sterilisasi terbaik dengan melihat pengaruh penggunaan natrium hipoklorit $5,25 \%$ dan alkohol $70 \%$ serta waktu perendaman terhadap penurunan kontaminasi. Pada penelitian ini terdapat 10 kelompok yang terdiri dari kelompok kontrol positif, kontrol negatif, perendaman dengan alkohol $70 \%$ selama 5 menit dan 10 menit, perendaman dengan natrium hipoklorit $5,25 \%$ selama 5 menit dan 10 menit, serta kombinasi natrium hipoklorit $5,25 \%$ dan alkohol $70 \%$ selama 5 menit dan 10 menit. Parameter pengamatan meliputi waktu pertama kontaminasi, persentase kontaminasi jamur dan bakteri, dan penampilan eksplan yang diamati selama 40 hari. Hasil penelitian pada penggunaan masing-masing desinfektan, baik alkohol $70 \%$ maupun natrium hipoklorit 5,25\% dengan waktu perendaman 10 menit menunjukkan tidak adanya kontaminasi jamur dan bakteri, tetapi pada perlakuan natrium hipoklorit $\mathbf{5 , 2 5 \%}$ terjadi perubahan warna eksplan menjadi kecoklatan. Kombinasi dari kedua desinfektan menunjukkan adanya kontaminasi jamur dan bakteri serta adanya perubahan warna eksplan. Sterilisasi eksplan daun sukun yang terbaik dapat dilakukan dengan cara perendaman menggunakan alkohol $70 \%$ selama 10 menit.
\end{abstract}

Kata Kunci: alcohol, daun sukun (Artocarpus altillis), eksplan, natrium hipoklorit, sterilisasi

\section{The Effect of Disinfectants and Soaking Time on the Sterilization of Breadfruit (Artocarpus altilis (Parkinson ex. F.A Zorn) Fosberg) Leaf Explants}

\author{
Nur Asni Setiani ${ }^{1{ }^{*}}$, Fitri Nurwinda ${ }^{1)}$, Dewi Astriany ${ }^{1)}$ \\ 1) College of Pharmacy Indonesia, Jl. Soekarno Hatta No. 354, Bandung, West Java \\ ${ }^{*}$ Email: nur.asni@stfi.ac.id
}

\begin{abstract}
Breadfruit leaves (Artocarpus altilis) is a herb that is widely used for herbal medicine. Tissue culture becomes an alternative method to enhance the productivity of breadfruit leaves and secondary metabolites that it produces. The success of plant propagation through tissue culture is determined by sterilization technique. This study aimed to obtain sterilization method by determining the effect of $5.25 \%$ sodium hypochlorite and $\mathbf{7 0} \%$ alcohol and soaking time on the decrease of contamination. In this study there were 10 groups consisting of positive control, negative control, immersion with $70 \%$ alcohol for 5 and 10 minutes, immersion with $5.25 \%$ sodium hypochlorite for 5 and 10 minutes, and combination of $5.25 \%$ sodium hypochlorite and $70 \%$ alcohol for 5 minutes and 10 minutes. Parameters observed were first time of contamination, percentage of fungal and bacterial contamination, and appearance of explants observed for 40 days. The results of the use of each disinfectant, $70 \%$ alcohol and $5.25 \%$ sodium hypochlorite with 10 minutes immersion time showed no presence fungal and bacterial contamination, but in the treatment of sodium hypochlorite $5.25 \%$, the explants become brownish. The combination of both disinfectants indicated the presence of fungal and bacterial contamination and the changes of explants color. The best sterilization technique of breadfruit leaves can be done by immersion using $70 \%$ alcohol for 10 minutes.
\end{abstract}

Keywords: alcohol, breadfruit leaves (Artocarpus altilis), explants, sodium hypochlorite, sterilization 


\section{PENDAHULUAN}

Daun sukun (A. altilis) adalah salah satu obat tradisional yang telah banyak dikenal masyarakat Indonesia. Secara tradisional daun sukun telah dimanfaatkan sebagai obat penyembuh sariawan, sakit gigi, gatal-gatal, rasa nyeri pada tulang sendi, infeksi telinga dan penyakit lainnya. Kandungan kimia pada daun sukun berupa saponin, tanin, flavonoid, polifenol, asam hidrosianat, asetilkolin dan riboflavin [1]. Penelitian yang pernah dilakukan menggunakan daun sukun (A. altilis) ialah aktivitas penangkap radikal bebas dari ekstrak fenolik daun sukun (A. altilis) [2] dan pengujian ilmiah tentang efek analgesik ekstrak etanol daun sukun ( $A$. altilis) pada tikus putih jantan galur wistar (Rattus norvegicus) [3].

Produktivitas dari daun sukun dapat ditingkatkan dengan cara kultur jaringan. Teknik kultur jaringan merupakan perbanyakan tumbuhan secara vegetatif. Kultur jaringan meliputi penanaman sel atau agregat sel, jaringan, dan organ tanaman pada medium yang mengandung gula, vitamin, asam-asam amino, garam-garam organik, air, zat pengatur tumbuh, dan bahan pemadat. Komposisi medium tumbuh tersebut ternyata sangat menguntungkan pula bagi pertumbuhan cendawan dan bakteri. Oleh karena itu, sterilisasi eksplan menjadi faktor penting dalam menentukan keberhasilan program kultur jaringan. Apabila eksplan yang kurang steril maka dimungkinkan mikroorganisme yang terbawa oleh eksplan tersebut akan tumbuh dengan cepat dan dalam waktu yang singkat akan menutupi permukaan medium pada eksplan yang ditanam atau yang biasanya disebut dengan kontaminasi, selanjutnya mikroorganisme tersebut akan menyerang eksplan melalui luka-luka akibat pemotongan. Disamping itu beberapa mikroorganisme melepaskan senyawa beracun ke dalam medium kultur yang dapat menyebabkan kematian jaringan [4].

Pemilihan metode sterilisasi eksplan yang tepat didasarkan pada jenis desinfektan dan lamanya waktu perendaman. Desinfektan merupakan bahan kimia yang digunakan untuk membunuh atau menurunkan jumlah mikroorganisme yang tidak diharapkan, misalnya bakteri, jamur, dan virus [5]. Desinfektan yang biasa digunakan dalam kultur jaringan diantaranya natrium hipoklorit, alkohol, bakterisida, dan fungisida [6]. Namun, desinfektan dan waktu perendaman memiliki pengaruh yang berbeda pada setiap spesies tanaman. Oleh karena itu, pada penelitian ini dilakukan sterilisasi menggunakan natrium hipoklorit 5,25\% dan alkohol $70 \%$ pada eksplan daun sukun (Artocarpus altilis (Parkinson ex. F.A. Zorn) Fosberg) dengan waktu perendaman yang berbeda untuk mendapatkan metode sterilisasi terbaik yang dapat menurunkan kontaminasi.

\section{METODE PENELITIAN}

Determinasi tanaman. Daun sukun hijau segar (A. altilis (Parkinson ex. F.A. Zorn) Fosberg) yang diperoleh dari daerah Cilampeni, Kabupaten Bandung dideterminasi di Laboratorium Farmakognosi Fitokimia, Universitas Padjajaran Bandung.

Pembuatan media. Komponen yang digunakan untuk membuat media dibuat larutan stoknya terlebih dahulu. Media pertumbuhan terdiri dari media Murashige and Skoog (MS - Caisson) dengan penambahan zat pengatur tumbuh Benzilaminopurine (BAP BBI Life Sciences). Sebanyak 4,43 g MS ditambahkan $30 \mathrm{~g}$ gula dan dilarutkan dengan akuades sampai $1000 \mathrm{~mL}$. Larutan dikondisikan pada $\mathrm{pH}$ 5,6-5,8 dengan menambahkan $\mathrm{KOH} 1 \mathrm{~N}$ untuk menaikkan $\mathrm{pH}$ dan HCL $1 \mathrm{~N}$ untuk menurunkan $\mathrm{pH}$. Larutan ditambah agar-agar $7 \mathrm{~g}$, kemudian diaduk dengan magnetic stirrer dan dipanaskan hingga mendidih. Benzilaminopurine dengan konsentrasi akhir 1 ppm ditambahkan ke dalam media. Larutan dituangkan ke dalam botol kultur $\pm 25 \mathrm{~mL} /$ botol dan ditutup dengan alumunium foil.

Persiapan eksplan. Sumber eksplan berupa daun sukun hijau segar (A. altilis) yang dipetik langsung dari pohonnya dan telah dibersihkan permukaannya. Daun dipotongpotong menjadi bagian kecil berukuran 2-3 cm.

Sterilisasi eksplan. Penelitian ini menggunakan Rancangan Acak Lengkap (RAL) dengan faktor perlakuan yaitu perbedaan desinfektan dan lama perendaman. Perlakuan dilakukan untuk desinfektan tunggal maupun kombinasi yang dibagi ke dalam 10 kelompok seperti pada Tabel 1 dan masingmasingnya dilakukan triplo. 
Tabel 1. Konsentrasi desinfektan dan lama perendaman eksplan daun sukun

\begin{tabular}{ccc}
\hline & \multicolumn{2}{c}{ Perlakuan } \\
\cline { 2 - 3 } Sampel & $\begin{array}{c}\text { Tahap I: } \\
\text { Natrium } \\
\text { hipklorit } \\
\text { 5,25\% }\end{array}$ & $\begin{array}{c}\text { Tahap II : } \\
\text { Alkohol }\end{array}$ \\
& $\mathbf{7 0 \%}$ \\
\hline S0a (kontrol & \multicolumn{2}{c}{ kontrol media yang } \\
positif) & disterilisasi, tidak ada eksplan \\
S0b (kontrol & kontrol media disterilisasi, \\
negatif) & eksplan tidak disterilisasi \\
S1 & 5 menit & 5 menit \\
S2 & 10 menit & 5 menit \\
S3 & 5 menit & 10 menit \\
S4 & 10 menit & 10 menit \\
S5 & - & 5 menit \\
S6 & - & 10 menit \\
S7 & 5 menit & - \\
S8 & 10 menit & - \\
\hline
\end{tabular}

Penanaman eksplan dan penyimpanan kultur. Penanaman eksplan dilakukan dalam LAF (Laminar Air Flow). LAF dibersihkan dengan alkohol 70\%, disinari lampu UV selama 1 jam, dan udara dibiarkan mengalir selama 30 menit. Tahap penanaman eksplan dilakukan secara aseptik di dekat api bunsen. Pada masing-masing botol medium ditanam satu potong eksplan daun sukun.

Variabel yang diamati. Variabel yang diamati meliputi waktu pertama kontaminasi muncul, persentase kontaminan (bakteri/ jamur) dan warna eksplan (hijau/coklat). Pengamatan dilakukan selama 40 hari.

$$
\begin{aligned}
\text { Kontaminasi } & =\frac{\text { botol terkontaminasi }}{\text { total bot ol }} \times 100 \% \\
\text { Warna eksplan } & =\frac{6 \mathrm{ksplan} \text { hijnu/coklat }}{\text { total botol }} \times 100 \%
\end{aligned}
$$

\section{HASIL DAN PEMBAHASAN}

Determinasi tanaman. Hasil determinasi menunjukkan bahwa tanaman yang digunakan termasuk famili Moraceae dengan nama spesies (A. altilis (Parkinson ex. F.A Zorn) Fosberg).

Waktu pertama kontaminasi. Kontaminasi berasal dari kontaminan eksternal berupa jamur maupun bakteri yang berasal dari lingkungan dan cenderung terbawa lewat alat maupun eksplan yang digunakan dalam penelitian, ataupun kontaminan internal yang pada umumnya berasal dari bakteri yang tumbuh di dalam jaringan tanaman. Kontaminasi yang sering terjadi pada kultur jaringan tanaman terdiri atas kontaminasi bakteri dan jamur. Bila terkena kontaminasi bakteri maka tanaman akan basah dan menyebabkan adanya lendir, sedangkan kontaminasi jamur tanaman akan lebih kering dan akan muncul hifa jamur pada tanaman yang terserang dan biasanya dapat dicirikan dengan garis-garis (seperti benang) yang berwarna putih sampai abu-abu.

Tabel 2. Waktu pertama kontaminasi pada

\begin{tabular}{|c|c|c|}
\hline \multirow[t]{2}{*}{ Sampel } & \multicolumn{2}{|c|}{ Waktu Pertama Kontaminasi } \\
\hline & Jamur & Bakteri \\
\hline S0a & $10 \mathrm{HST}$ & Tidak ada \\
\hline SOb & 5 HST & 2 HST \\
\hline S1 & $3 \mathrm{HST}$ & 5 HST \\
\hline $\mathrm{S} 2$ & $14 \mathrm{HST}$ & Tidak ada \\
\hline S3 & 7 HST & 7 HST \\
\hline S4 & Tidak ada & $28 \mathrm{HST}$ \\
\hline S5 & $10 \mathrm{HST}$ & $10 \mathrm{HST}$ \\
\hline S6 & Tidak ada & Tidak ada \\
\hline S7 & 2 HST & Tidak ada \\
\hline S8 & Tidak ada & Tidak ada \\
\hline
\end{tabular}
eksplan

Berdasarkan pengamatan yang dilakukan selama 40 hari menunjukkan bahwa rata-rata waktu pertama kontaminasi bervariasi seperti pada Tabel 2. Sampel yang menunjukkan waktu pertama kontaminasi tercepat adalah perlakuan kontrol negatif (SOb) tanpa sterilisasi yaitu 2 Hari Setelah Tanam (HST). Waktu kontaminasi pertama yang paling lama adalah 28 HST pada sampel S4 dengan kombinasi perendaman natrium hipoklorit $5,25 \%$ dan alkohol $70 \%$ masing-masing selama 10 menit. Sedangkan penggunaan tunggal natrium hipoklorit 5,25\% selama 10 (S8) dan alkohol 70\% selama 10 menit (S6), pada keduanya tidak ditemukan adanya kontaminasi hingga hari ke-40. Penggunaan desinfektan tunggal maupun kombinasi serta lamanya waktu perendaman memengaruhi waktu kontaminasi.

Persentase kontaminasi. Tingkat kontaminasi eksplan dipengaruhi oleh banyak faktor seperti media tanam, lingkungan kerja, alat eksplan, dan asal eksplan khususnya yang berasal dari lapangan. Berdasarkan Gambar 1, pada kontrol S0b menunjukkan angka persentase eksplan terkontaminasi terbesar 
yaitu sebesar 100\%, baik jamur maupun bakteri. Hal ini menunjukkan bahwa penggunaan bahan sterilisasi eksplan sangat dibutuhkan untuk keberhasilan teknik kultur in vitro. Tanpa penggunaan bahan sterilisasi maka eksplan akan terkontaminasi sehingga perbanyakan tanaman sukun secara in vitro tidak akan berhasil.

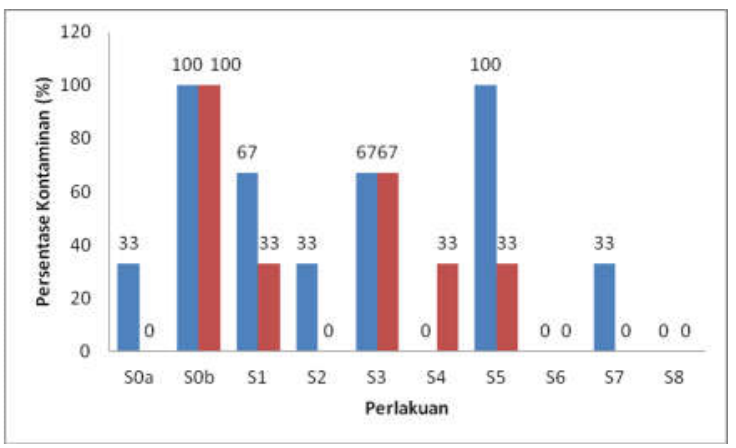

Gambar 1. Tingkat kontaminasi eksplan daun sukun (A. altilis). Keterangan: merah $=$ bakteri, biru $=$ jamur

Sterilisasi dengan menggunakan natrium hipoklorit 5,25\% dengan perendaman 5 menit (S7) menunjukkan kontaminasi sebanyak 33\% sedangkan perendaman dengan natrium hipoklorit 5,25\% selama 10 menit (S8) tidak menunjukkan adanya kontaminasi $(0 \%)$. Hal ini menunjukkan bahwa lamanya perendaman dapat memengaruhi tingkat kontaminasi. Natrium hipoklorit banyak digunakan karena sangat efektif membunuh bakteri dengan cara merusak membran sel bakteri. Senyawa hipoklorit mampu membersihkan mikroorganisme yang ikut dalam bahan tanaman, menghilangkan pertikel-partikel tanah, debu dan lain-lain. Jika senyawa ini diberikan dalam konsentrasi rendah dan lama perendaman singkat tidak terlalu efektif dalam mengendalikan kontaminasi pada eksplan [7]. Semakin singkat waktu perendaman dengan natrium hipoklorit maka eksplan semakin rentan terhadap patogen. Namun, apabila semakin lama perendaman dengan natrium hipoklorit maka perkembangan jaringan eksplan menjadi terhambat yang ditandai dengan browning (warna kecoklatan) pada eksplan [8]. Alkohol membunuh bakteri dengan mekanisme denaturasi protein sel bakteri. Penggunaan alkohol $70 \%$ selama 5 menit (S5) menunjukkan kontaminasi jamur sebesar $100 \%$ dan bakteri 33\%, sedangkan penggunaan alkohol $70 \%$ selama 10 menit (S6) tidak menunjukkan adanya kontaminasi, sedangkan untuk penggunaan kombinasi desinfektan alkohol 70\% dengan natrium hipoklorit 5,25\% dengan waktu perendaman 5 menit dan 10 menit menunjukkan rata-rata kontaminasi sebesar 33,3\%. Hasil ini menunjukkan bahwa jenis desinfektan memengaruhi tingkat kontaminasi, begitupun dengan lamanya waktu perendaman.

Persentase penampilan eksplan. Pemberian berbagai macam desinfektan dan lamanya perendaman memang dapat menurunkan tingkat kontaminasi, tetapi dapat juga memengaruhi penampilan eksplan seperti pada Gambar 2.

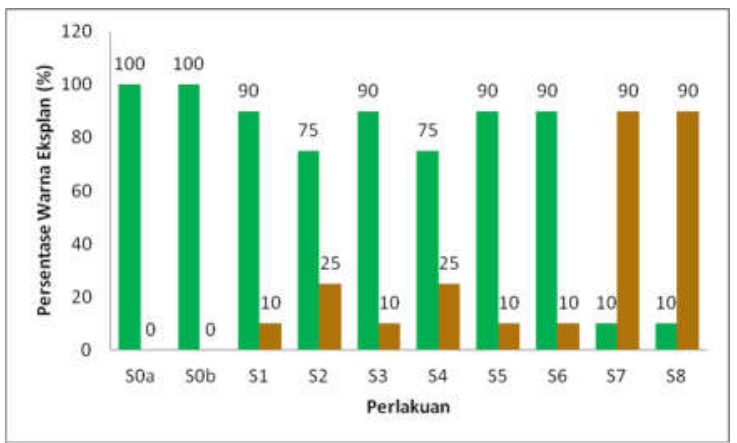

Gambar 2. Persentase Warna Eksplan (A. altilis). Keterangan: hijau $=$ eksplan berwarna hijau, coklat $=$ eksplan berwarna coklat.

Pada Gambar 2 terlihat eksplan sampel kontrol negatif yang tidak diberi bahan sterilisasi berwarna hijau segar walaupun penuh kontaminasi. Ketiadaan bahan sterilisasi ternyata tidak mengubah warna dan tekstur eksplan. Hal ini menunjukkan bahwa desinfektan memengaruhi warna eksplan.

Pada sampel yang menggunakan natrium hipoklorit $5,25 \%$, terlihat adanya perubahan warna eksplan. Eksplan dengan perendaman selama 10 menit mempunyai warna lebih coklat dibandingkan dengan perendaman 5 menit. Hal ini disebabkan senyawa natrium hipoklorit $5,25 \%$ yang dapat mengubah struktur dan tekstur eksplan. Eksplan dengan perendaman natrium hipoklorit yang lebih lama menyebabkan permukaannya memar atau mengalami pencoklatan. Semakin lama perendaman eksplan dengan natrium hipoklorit $5,25 \%$ maka semakin luas permukaan eksplan yang mengalami pencoklatan dan semakin banyak jumlah eksplan yang berwarna menjadi coklat [8].

Pada perlakuan sterilisasi eksplan dengan menggunakan alkohol $70 \%$ menghasilkan eksplan yang berwarna hijau dan segar. Waktu 
perendaman menggunakan alkohol $70 \%$ tidak mengubah warna dari eksplan.

Pemaparan eksplan yang lebih lama dengan alkohol $70 \%$ dan natrium hipoklorit $5,25 \%$ akan menyebabkan kerusakan pada eksplan yang tidak dapat balik (irreversible). Pemaparan eksplan dengan bahan sterilan dalam periode waktu yang panjang akan menyebabkan eksplan mengalami pencoklatan (browning) bahkan dapat menyebabkan kematian pada eksplan [7]. Pada kelompok perlakuan yang menggunakan kombinasi bahan sterilisasi natrium hipoklorit 5,25\% dan alkohol $70 \%$, eksplan terlihat hijau agak coklat dan agak segar.

Berdasarkan penelitian, perlakuan perendaman menggunakan alkohol $70 \%$ selama 10 menit (S6) menunjukkan hasil terbaik yaitu dapat menekan munculnya kontaminasi serta lamanya perendaman eksplan pun tidak mengubah warna eksplan.

\section{KESIMPULAN}

Jenis desinfektan yang digunakan serta lamanya perendaman berpengaruh terhadap penurunan kontaminasi serta penampilan warna eksplan. Sterilisasi menggunakan alkohol $70 \%$ dengan lama perendaman 10 menit mampu menghilangkan kontaminan pada eksplan tanpa mengubah warna eksplan.

\section{UCAPAN TERIMA KASIH}

Terima kasih kepada Sekolah Tinggi Farmasi Indonesia yang telah menyediakan berbagai fasilitas penunjang penelitian.

\section{DAFTAR PUSTAKA}

[1] Mardiana L (2012) Daun ajaib tumpas penyakit. Penebar Swadaya, Jakarta, Hal.172.

[2] Suryanto E, Wehantouw F (2009) Aktivitas penangkap radikal bebas dari ekstrak fenolik daun sukun (A. altilis). Chemistry Progress 2(1): 1-7.

[3] Bakarbessy WH, Wullur AC, Lolo WA (2016) Uji efek analgesik ekstrak etanol daun sukun (A. altilis) pada tikus putih galur wistar (Rattus norvegicus). PHARMACON Jurnal Ilmiah Farmasi 5(1): 220-227.
[4] Zulkarnain (2009) Kultur jaringan tanaman. PT Bumi Aksara, Jakarta, Hal. 20-35.

[5] Rismana (2002) Sanitasi dan desinfektan, langkah awal yang efektif mencegah penyakit. Infomedia, Jakarta, Hal. 169.

[6] Purwanto AW (2008) Sansievera flora cantik penyerap racun. Kanisius, Yogyakarta.

[7] Farooq SA, Farooq TT, Rao TV (2002) Micropropagation of Annona squamosa L. using nodal explants. Pakistan Journal of Biological Sciences 5(1): 43-46.

[8] Rismayanti, Hamzah F (2010) Pengaruh pemberian chlorox $(\mathrm{NaOCl})$ pada sterilisasi permukaan untuk perkembangan bibit Aglaonema (Donna carmen) secara in vitro. Prosiding Seminar Ilmiah dan Pertemuan Tahunan PEI dan PFI XX Komisariat Daerah Sulawesi Selatan. 